\title{
EPIMELIA PRINCIPLE AS A METHODOLOGICAL BASIS FOR HEALTH-PROTECTION ACTIVITY OF FUTURE TEACHERS IN THE PROCESS OF PHYSICAL EDUCATION
}

\section{Chernihivska S. A., Matrosov S. O.}

\section{INTRODUCTION}

There are various definitions of human ill health; however, one of the most felicitous ones in the context of our study is the limited freedom of life. It is quite obvious that a more or less capable person seeks to get rid of such restriction. The first European practices of self-care, including care about health, appeared in Ancient Greece as part of a separate philosophical system. Later on, the focus of pedagogical practice, which, inter alia, forms a person's attitude to himself, to his own health, was determined with the level and peculiarities of the development of a society, as well as its demands and expectations.

The direct connection and dependence of the content of pedagogical practice in the context of a person's attitude to his health on the dominant ideology in the society and the nature of production can be traced at all stages of human civilization and can be illustrated with an example of emergence and development of physical education as the discipline in various countries.

At the end of the XIX century, an essentially utilitarian physical education began to develop in the majority of European countries, later spreading to the USSR. The focus of this discipline was stipulated in these countries with the efforts to form a predetermined set of physical qualities, motor skills and abilities, to train young people to execute the military commands clearly as required by the production that had a significant component of physical labor, as well as total military training of the youth. In contrast, in the United Kingdom, Canada and the United States, a similar discipline was formed, which focused on hygiene, recreation and sports.

At the end of the XX and the beginning of the XXI century, nation-specific and class political priorities gave way to recognition of the importance of adhering to universal values and pursuing the international stability. Therefore, the guidelines for sustainable development in each country are taken as a reference. Total militarization of the youth becomes unnecessary due to formation of the professional armies. New threats are emerging, including the negative consequences of urbanization, which intensify the search for fundamentally new approaches. Achievements in the nation's health and life expectancy values are considered to be the main criteria for the quality of life in any given country, as they summarize all available achievements in the field of economy, education, life, health and leisure. 
It is obvious that such qualitative changes in public life required a revision of ideas about the primacy of physical training in the general system of training the graduates of higher education institutions for future employment. Instead, there appeared the ideas about the importance of forming a mobile specialist with a high level of mental capacity and a sustainable health, who is ready - due to high adaptability - to take various professional positions periodically, regardless of the qualification indicated in the diploma; a specialist who is able to restore their efficiency quickly and effectively. Active search for the opportunities to disseminate the accumulated basic healthcare knowledge is being carried out, and efforts are being made to find new ways of disseminating, assimilating and using it.

Finally, the idea of a human himself reached a qualitatively different, higher level, which is beyond the natural science knowledge that previously was the exclusive basis of all pedagogical and medical developments. Along with natural science knowledge, the theory and practice of education gradually incorporates the methodological knowledge and knowledge of activities. With the full right and increasingly often, we begin to consider the world we live in not only as natural, but also as the world that largely depends on human thinking and activity.

Thus, the transit in the pedagogical sphere and gradually in the medical sphere now to the category of health through the mentally active picture of the world, which corresponds to the main idea of creative healthcare science, concept and technology of so-called 'non-professional physical education' of students is a fundamentally new and promising way ${ }^{1}$. Until recently, addressing the issue of human health with a purely bodily emphasis was the exclusive prerogative of religious and, on the other, natural-scientific pictures of the world formed by the church service of the priesthood or medical practices of doctors, respectively. Thus, students' health-protection

${ }^{1}$ Томенко О.А. Особливості теоретичних уявлень майбутніх вчителів фізичної культури стосовно питань аксіологічного та здоров'язбережного спрямування. Спортивна наука України. 2013. № 1. С. 44-47. URL: http://www.sportscience.org.ua/index.php/Arhiv.html.

Томенко О., Матросов С. Відмінності у показниках соматичного здоров'я, рухової активності, теоретичної підготовленості й мотиваційної сфери старшокласників та студентів залежно від статі. Педагогічні науки: теорія, історія, інноваційні технології. 2018. № 9 (83). С. 113-123.

Чернігівська С.А. Інноваційна технологія непрофесійної фізкультурної освіти студентів, звільнених від практичних занять 3 «Фізичного виховання» : дис. ... канд. наук з фіз. вих. і спорту : 24.00.02. Дніпропетровськ, 2012. 290 с.

Чернігівська С.А. Модель будівничого власного здоров'я для інноваційної педагогічної технології непрофесійної фізкультурної освіти студентів, звільнених від «Фізичного виховання». Спортивний вісник Придніпров'я. 2011. № 2. С. 38-40.

Чернігівська С.А., Шевяков О.В. Особливості психічних станів студентів, звільнених від практичних занять 3 «Фізичного виховання». Вісник Чернігівського державного педагогічного університету. 2011. Вип. 91. С. 491-495. 
activities should be based on clear methodological foundations (for example, sound principles, axiomatic principles that originate from the history of philosophical thought). Accordingly, the goal of this article is to substantiate the anthropic epimelia principle as a methodological basis for healthprotection activities of students - future teachers.

\section{The concept of non-professional physical education and build-up own health}

The experience of teaching healthcare disciplines, which grew out of medical knowledge about human health, has revealed complications that do not allow to expect any significant social consequences in a form of caring attitude among the young people to their health. This is naturally due to the limited possibilities of the natural science picture of the world and the means of traditional didactics. This statement would not seem an exaggeration if the end result in the personality formation would be not just a transfer of scientific knowledge about health to students, but their formation as the subjects of building up their own health, which the medical healthcare science does not qualify for. According to V. Prykhodko, the author of the concept of creative healthcare science, in contrast to pedagogical healthcare science, which is based solely on application of classical didactical means for transmission of information and knowledge; it focuses on the means that help to become a physically-active person that builds up his own health ${ }^{2}$.

We are talking about a person, who takes responsibility for his own health and - for example - after being qualified to the 3rd disablement group, unlike most people who expect to be assigned the 2 nd group, seeks to cure his disability with daily and conscious efforts to perform exercises recommended by a doctor, keep a balanced diet, and to spend a lot of time moving in the fresh air etc.

Involvement in the formation of personality, in addition to religious, philosophical and scientific paradigms, in which human health was used to be considered until recently (spirit and soul, psyche and corporeality), as well as the mentally active picture of the world, allows to hope for realization by the person of really active attitude to management of own health according to the following pattern: thinking - analysis of own condition - choice of safe and effective means to influence own condition activity. These efforts stipulate the emergence of a new direction of pedagogical healthcare science, i.e. creative healthcare science.

After all, health condition is determined not only with the innate state of corporeality, but also with the accompanying behavioral moments, peculiarities of mental and vital activities of a human being. In fact, these circumstances are highlighted in the well-known definition by the World

\footnotetext{
${ }^{2}$ Приходько В.В. Стратегія реформи національної вищої школи : монографія. Дніпропетровськ : Журфонд, 2014. 460 с.
} 
Health Organization, which emphasizes that health is not only the absence of disease, but also the state of complete physical, mental and social wellbeing. It follows that 'health' and the absence of disease are not identical human conditions. Medicine, which is focused on diagnostics and treatment by establishing the norm and pathology, seeks a disease and a way to fight it. Meanwhile, good and sustainable health is not accidental, but usually manmade. Awareness of own healthy condition is peculiar to an active person, as a rule, who consciously and systematically makes significant efforts to optimize his living.

Thus, health build-up is not a transition to the practice of self-treatment, but a system corresponding to the value ('for me it is extremely important to be healthy') and the possibilities of a particular person's life, which provides for his creative activity aimed at formation and maintenance of optimal health. Health build-up creates the prospects for significant intensification of the medicine capabilities through participation of a properly healthcare-educated and active person, who - together with healthcare professionals - strives for fighting the existing pathologies and improving his psychophysical condition. After all, today it is obvious that "the main task of education is not to meet the needs of the state, but the needs of the society as a whole and each of its members. Production-oriented education is replaced with education based on socio-cultural and personal dominance... In the XXI century, the worldview and pedagogic function of education gains crucial importance",3.

Formation of a person with self-determination to build-up own health, who has given up the usual passive but so comfortable position of a health care consumer is an important theoretical and practical problem for modern education systems at the beginning of the XXI century. Here it is appropriate to mention the thesis of the German philosopher H.-G. Gadamer: "The general essence of human education is that man makes himself a spiritual being in all respects. He who gives himself to the elements of education is uneducated"4.

The concept of non-professional physical education (NPE) for people with different levels of health, substantiated by V.V. Prykhodko and S.A. Chernihivska, is a truly historical phenomenon that enriches physical culture as a part of the world culture. This statement should be considered an obvious fact, because the authors' research and development are based on the recognized achievements of mankind in such areas as philosophy, methodology of mental activity and sciences that currently substantiate the pedagogical practice related to health, including:

- ancient philosophical and educational concept (epimelia concept);

- theory of education and pedagogical anthropology;

${ }^{3}$ Приходько В.В. Стратегія реформи національної вищої школи : монографія. Дніпропетровськ : Журфонд, 2014. С. 40.

${ }^{4}$ Гадамер Х.-Г. Истина и метод: Основы филос. Герменевтики / пер. с нем. ; общ. ред. и вступ. ст. Б.Н. Бессонова. Москва : Прогресс, 1988. С. 54. 
- the concept of physical education of a doctor and a teacher of the early XX century by P.F. Lesgaft;

- methodology of mental activity.

The provisions of philosophy, pedagogy and psychology concerning education and upbringing, thinking and consciousness, human health, living and activity are also used.

Formation of theoretical grounds for the practice of human NPE should be considered as a natural stage in the genesis of a new cycle of education, which is characterized with emergence of a person who has mastered the knowledge of project type and successfully solves the problem of correlating and using the scientific knowledge in his developing activities.

This feature of modern education has been seen as an objective trend since the mid-XX century. It was noted that the university of the new cycle of education is notable for its desire to obtain and use not only traditional knowledge, but also knowledge about the human world as a world of thinking and acting ${ }^{5}$. We can put it this way - if the religious picture of the world is directly related to the church, and natural science - to the objects of nature (including man and all living things) and material production, the mentally active picture of the world is associated with modern education systems aimed at formation of an active person.

We will also give an answer to a natural question, why do we lay emphasis on education as a priority pedagogical process? Arguing our understanding, we refer to the conclusion by V. Rozanov: "In eras that have almost come to their end, when all guiding principles of life are weak and people are confused, indecisive, the existence of each human is shaky and can only be strengthened with personal effort" epochs, everything that is done for education is essentially insignificant, only a game that closes the eyes to the future - like building up a wall on the foundation, the slabs of which are carefully laid in the ground falling from the volcanic vent. Despite they are laid carefully, despite the diligent work of the builders - in a minute they all and the results of their work will be gone"7. Instead, only human education remains perspective.

A contemporary of Rozanov, who also experienced the collapse events in Russia at the turn of the XIX and XX centuries, M. Kareev defined the essence of humanistic requirements for the educational process. In his book titled "Ideals of General Education", he wrote: "The student's personality can be a goal for the school or a goal itself, or only a means for the goals, which are alien for such personality $<\ldots>$ Who sees an independent ego in the student's personality, which carries the goal of its existence in itself, he

5 Никитин В.А. К представлению об исторических циклах университетского образования. Вопросы методологии. 1991. № 2. С. 67-68.

${ }^{6}$ Розанов В.В. Сумерки просвещения. Москва : Педагогика, 1990. С. 129-130.

${ }^{7}$ Там само. С. 130-131. 
will not allow himself to think that the school must do anything other than

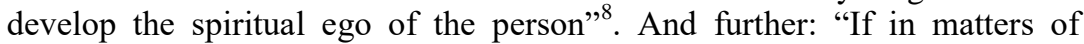
education we put forward, say, only the interests of national identity or civil service, completely ignoring the needs of a living human, which has the purpose of his existence in himself, we would see in him only one of the tools of national self-preservation or one of the wheels of the mechanism of government. After all, it has been said long ago: "The Sabbath was made for man, not man for the Sabbath". Thus, "education, which aims to develop the personality, contributes in such a way to emergence and intensification of personal initiative, a critical attitude to the surrounding cultural and social reality and the desire to implement personally realized truth and personally realized justice" $" 10$.

It is these last theses that bring the processes of quality education of young people with focus not only on a certain qualification but also, among other important things, on building-up own health, to the forefront for our country, as well as for the countries of the former socialist camp, which have experienced the breakdown of socio-economic formation and endure deep political and social transformations.

\section{Substantiation of the anthropic epimelia principle as a methodological basis of health protection activities of future teachers}

One of the fundamental provisions of the non-professional physical education concept is to take into account and use the epimelia principle formed in Western antiquity. As an important reference point for educational systems, epimelia (or self-care) requires a shift of view, attention from the surrounding world, from other objects to oneself. It is an observation what a person thinks, what happens inside of his mind. Epimelia also means an action by which a person not only takes care of himself, but also changes, purifies and transforms himself ${ }^{11}$. Meanwhile, there are three types of skills (or techne), i.e. three types of attitudes towards the student, which are necessary to educate a youth person with the epimelia approach:

- mentoring by example of an active teacher, other significant and influential people;

- mentoring by knowledge;

- mentoring in difficult situations, which forms the ability to cope with numerous difficult and extreme situations that a person constantly faces (Socrates' techne).

${ }^{8}$ Кареев Н. Идеалы общего образования. Alma mater. 1992. № 1. С. 82.

${ }^{9}$ Там само. С. 83 .

${ }^{10}$ Там само. С. 84.

11 Фуко М. Герменевтика субъекта. Социо-Логос / пер. с англ., нем., франц. Москва : Прогресс, 1991. С. 284-285. 
First of all, let us emphasize an interesting and important for us positive feature of extremality for the personality formation, which was once noticed by V. Rozanov: "Work and need nurture spiritual health and strength; the genius mind or (especially) character is brought up by misfortune, undeserved and long-lasting grief" ${ }^{\prime 2}$. It is clear that the cases of fruitful influence of extremality on human development alternate with less favorable effects of stress; however, the positive effect of extremality mechanism should be studied for practical use in solution of issues related to pedagogy of development.

An active student, in the process of his formation, according to the epimelia concept, must strive not only for any knowledge to replace his ignorance, but to become a subject of activity. He must become a true subject, which is determined with his responsible attitude to his ego. Thus, we are talking not only about the processes of educare (education), but about the desire to ensure educere (leading) of a human to self-development within the above guidelines, according to the epimelia principle. Comprehensive development of ego is seen as the ultimate and only goal, namely, self-care. More specifically, it is an activity of education, which is focused on one's own ego and carried out in relation to oneself. After all: "education is the backbone of an individual in the face of events" ${ }^{\prime 3}$.

A natural question arises, at what age we can approach the formation of a young person as a subject responsible for building-up health and personal life? Today it is widely accepted that only after reaching puberty (conditionally at the age of 14-16) the process of "birth of the spiritual essence of a human" starts, "he acquires intelligence, the ability to think and abstract" $"$. However, it is too early to expect the highest development of intellectual functions at this stage: "The only activity that can qualify for adequate compliance with the uniqueness of the social situation of adolescent development - is the self-determination activity"15. However, the role of self-determination of the individual should not be underestimated: "The way of self-determination is $<\ldots>$ the way of 'salvation' from empirical dependence" of living conditions. Self-determination presupposes 'a person's ability to get out, pull himself out of causal dependence, from his past, from his previous state". To do this, a person should find or create an

\footnotetext{
${ }^{12}$ Розанов В.В. Сумерки просвещения. Москва : Педагогика, 1990. С. 128.

13 Фуко М. Герменевтика субъекта. Социо-Логос / пер. с англ., нем., франц. Москва : Прогресс, 1991. С. 293.

14 Загорский В.В. «Вальфдорское» преподавание химии. Химия в школе. 1995. № 3. C. 11.

15 Зинченко В.П. Совокупная деятельность как генетически исходная единица психического развития. Психологическая наука и образование. 2000. № 2. С. 89.
} 
internal mechanism "with which he will begin to 'reveal' himself - he will discover new feelings and ideas"16.

Yu. Repetskyi in the article 'The Concept of Personal SelfDetermination: the Initial Provisions and an Attempt to Verify them' notes the following circumstance. One of the central, system-forming factors of personal self-determination process is the activity aimed at obtaining a positive personal meaning through reflexively conditioned search and development of sources of positive self-esteem ${ }^{17}$. Moreover, self-awareness is primarily the process by which a person cognizes himself, develops an attitude to himself. It is a subjective activity involving the conscious, purposeful application of cognitive processes aimed at forming, maintaining, stabilizing, or changing the ego. Meanwhile, the attitude itself (or the meaning of ego) "is born through the collision of ego with the motives (which determine the need for self-realization), and is the result of selfassessment and a sense of devotion or sympathy for oneself. The attitude to oneself, revealing the emotions and value a person has to oneself, performs as feedback in the life of the individual, adequately informing him how much successful his self-realization is" ${ }^{\prime 18}$. As a result of the process of selfdetermination, Repetskyi sees the construction of a life plan, which - in our opinion - may take place in the process of education (self-education) of a person, which actually lasts a lifetime. Thus, finding an idea of oneself (i.e. what kind of person I want to be, including in terms of health) closes the semantic integrity of the individual.

Since the idea of life, its grand purpose, is a cognitive-experienced formation, then "the idea is very closely related to the basic personal motives, including the motives of self-realization"19. Therewith, the author distinguishes only two most general strategies of personal self-determination and all of them are determined with reflexive activity. The first one is realized through awareness of the given current state of affairs. Awareness goes 'from the bottom up' - from realization of specific, local goals (plans) to understanding the general plan of life. In the second, active sense - is the formation of 'proper' from the abstract plan (grand purpose) to its development in the form of specific goals and objectives and the search for personal meaning of life $\mathrm{e}^{20}$. As you can see, in the first case, the processes of self-determination and self-realization go in parallel, while in the second case self-determination precedes the actual self-realization of human.

\footnotetext{
${ }^{16}$ Буякас Т.М. Проблема и психотехника самоопределения личности. Bonpocbl психологии. 2002. С. 34.

17 Репецкий Ю.А. Концепция личностного самоопределения: исходные положения и попытка их верификации. Нова парадигма. Вип. 2. 1997. С. 12.

${ }^{18}$ там само. С. 8-9.

${ }^{19}$ Там само. С. 10.

${ }^{20}$ Там само.
} 
It is here that we approach the understanding of the deep meaning of the anthropological principle and the anthropotechnical action of human in the context of his education. "Anthropological principle is not a theory, however, an original psychological explanation of child development serves as $\langle\ldots\rangle$ the formation of authorship and universality of self-development" ${ }^{21}$. The anthropological principle "focused on human development $<\ldots>$ gifted with subjectivity, is the ability to transform own lives into a subject of practical transformation" 22 .

Returning to the epimelia principle, we note that self-care is closely related to a human desire to save oneself and others. However, to save oneself means to maintain oneself in a stable condition, which nothing can disrupt, no matter what happens around. "Save" here is used to denote the activity carried out throughout the lifetime and executed only by the subject himself.

M. Foucault emphasizes: "There is an inversion of relationship between salvation of others $\langle\ldots\rangle$ and salvation of oneself $\langle\ldots\rangle$ According to Plato, it is worth taking care of oneself, taking care of others, and if a person saved others, so he saved himself $<\ldots>$ Salvation of others is a consequence, the result of self-care" 23 .

The process and results of self-determination are determined with the degree of self-trust. Furthermore, "the level of self-trust is associated with subjective perceptions of their own ability to act accordingly" 24 . Hence, "internal changes in a personality can be directed in two opposite directions - towards creative development and towards self-destruction". "Awareness of one's own capabilities," T.P. Skrypkina notes, "precedes the goal-setting and is directly related to the choice of goals. Empirical awareness of own capabilities presupposes the experience of 'I can', which should be considered as a reflexive perception of one's capabilities". And further: "One experience 'I can' is not enough, willpower is required to carry out any activity; however, this is the next stage. The experience of 'I can' multiplied by volitional effort generates the same vector 'goal - motive', which initiates the activity itself (ibid.). Therefore: "Trust acts as a mechanism, a means that combines the past and the future of a human into one holistic process <...> The optimal level of self-trust ultimately involves mastering the ability to self-realization in the process of life" ${ }^{\text {"25 }}$.

${ }^{21}$ Мясоед П.А. Антропологический принцип и проблемы психологии развития. Вопросы психологии. 2000. № 5. С. 124.

22 Слободчиков В.И. Антропологический принцип в психологии развития. Вопросы психологии. 1998. № 6. С. 12.

23 Фуко М. Герменевтика субъекта. Социо-Логос / ер. с англ., нем., франц. Москва : Прогресс, 1991. С. 301.

${ }^{24}$ Скрипкина Т.П. Доверие к себе как условие развития личности. Bonpocbl психологии. 2002. № 1. С. 101.

${ }^{25}$ Там само. С. $102-103$. 
M. Foucault, who studied the epimelia concept/cura sui ("take care of yourself'), identifies three phases of development in its formation: 1) SocraticPlatonic: emergence of the concept of 'epimelia/cura sui' in philosophy; 2) the golden age of self-care and the culture of one's ego (II and I centuries B.C.); 3) transition from philosophical pagan asceticism to Christian asceticism (IV and V centuries A.D. $)^{26}$. It is known that it was exactly Christianity that enriched this ancient thought with the idea of personality and introduced an understanding of humanity in its modern sense.

This is why Christianity is recognized as the foundation of a common European cultural identity, so we may not ignore the topic of religion in this article, which - in our opinion - will initiate a number of publications by other medical colleagues. "Physical health is one of those few aspects of life that everyone cares about. We all strive to know the secrets of a high-quality life. In our opinion, this is primarily the adherence to the eternal principles of Christian morality, which is able to give a person a healthy lifestyle"27.

Regarding the history of the issue, emergence of the first ideas about a healthy lifestyle is associated with the name of Hippocrates, who defined it in his treatise "On a Healthy Lifestyle": "We should arrange our way of life according to age, season, habits, country, place, body structure, so that we can withstand heat and cold, because this is the only way to achieve good health". As for the category of health, even in ancient Greece, "the axiological aspect of the concept of 'health' began to emerge, i.e. its social significance or universal value was especially emphasized. In the ancient world $\langle\ldots\rangle$ good health is the main criterion that ensures the intellectual development of the younger generation" 28 .

The Christian religion, which gave instructions about the way of salvation, actively operates with the concept of 'asceticism'. In ancient Greek history, 'asceticism' means gymnastic exercises, and later in philosophy - achievement of virtues through exercise. The Apostle Paul (1 Corinthians, IX, 24-27) uses this concept in two senses: a feat for gymnastics and a feat for spiritual creation. "In the works of the apostolic fathers, the term 'asceticism' came into general use and means: fasting,

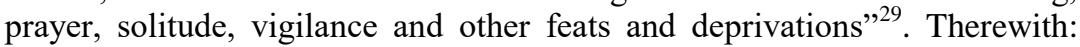

${ }^{26}$ Фуко М. Герменевтика субъекта. Социо-Логос / пер. с англ., нем., франц. Москва : Прогресс, 1991. С. 284-311.

27 Кузьмик В. Принципи християнської моралі - основа здорового способу життя сучасної людини. Острозька Академія. Наукові записки. Т. 3. Виховання молодого покоління на принщипах християнської моралі в процесі духовного відродження Украӥни. 2000. С. 373.

${ }^{28}$ Сущенко Л.П. Історико-філософський аспект становлення поняття «здоровий спосіб життя» людини у давньому світі та середніх віках. Нова парадигма. Вип. 2. 1997. С. $42-47$.

${ }^{29}$ Концевич И.М. Стяжание духа святаго. Киев : Изд. Экзарха всей Украины Митрополита Киевского и Галицкого, 1990. 52 с. 
"A person may not limit himself as though only to mechanical mastering of mysteries. He must have a desire and an effort, of which the Savior speaks: "The kingdom of heaven is taken by force, and those who make the effort attain it" (Matthew, XI, 12). Salvation requires cooperation of both grace and free will of a human, which must follow the path of ascetic feats.

According to L.P. Sushchenko, the concept of 'take care of yourself', which existed before Christianity, reappeared in the Alexandrian spiritual tradition, both in the form of Christian care in Philo and Plotinus, and in the form of Christian asceticism of Gregory of Nyssa. In the Middle Ages, the spiritual component of the healthy lifestyle comes to the fore. "In fact, general religiosity is becoming a powerful incentive to perform all religious rituals, including health and hygiene rules. The Bible, as the basis of Christianity, acts as a kind of preacher of a healthy lifestyle" ${ }^{30}$.

We also have information about the respect for a healthy lifestyle in Kievan Rus in the period after it was baptized. The term 'health' is found in ancient written records. For example, the Russian princes wished health to the Polovets khan Bonyak (1140), and the ambassadors of the Polovets khan to prince Svyatoslav (1147). According to the 'Teachings' by Vladimir Monomakh (1053-1125), the basis of a healthy lifestyle is a productive work, the fight against laziness and the constant improvement of own physical and mental abilities. Mental health should base on the religious commandments and include a set of high moral and ethical actions towards others. Physical activity was a mandatory element of human life, in a form of frequent catching games, military exercises and military campaigns. Conditioning, balanced nutrition and personal hygiene were also part of a healthy lifestyle. The main method to form a healthy lifestyle in children was the personal example of parents and elders ${ }^{31}$.

The Christian religion treats asceticism differently. For example, the Catholic Church views it as something obligatory only for the monks, and in relation to the laity as 'beyond what is proper'. "And Orthodoxy teaches that asceticism, although in varying degrees and forms, is obligatory for all Christians without exception, according to the Savior, who requires his followers to make an effort" ${ }^{\prime 32}$.

Almost two thousand years passed before J.-J. Rousseau, G.W.F. Hegel and I. Kant re-considered the phenomenon of human activity and activityforming education, revealed their mechanisms, and showed how the ego changes and transforms itself. The essence of the anthropological principle

${ }^{30}$ Сущенко Л.П. Історико-філософський аспект становлення поняття «здоровий спосіб життя» людини у давньому світі та середніх віках. Нова парадигма. Вип. 2. 1997. C. 44-45.

${ }^{31}$ Чернышевский Н.Г. Антропотехнический принцип в философии. Избр. филос. соч. : в 3 т. Москва : Госуд. изд-во политич. литер., 1951. Т .3. С. 215-216.

${ }^{32}$ Концевич И.М. Стяжание духа святаго. Киев : Изд. Экзарха всей Украины Митрополита Киевского и Галицкого, 1990. 52 с. 
in the 'moral sciences' was formulated by M.G. Chernyshevsky. "This principle is that a human should be seen as one being with only one nature, so as not to cut human life into different parts $\langle\ldots\rangle$ to consider each side of human activity or as the activity of the whole organism. <..,> or if it is a special assignment of any special organ of the human body, then consider such organ in its natural connection with the whole organism"33.

Anthropology today considers and studies a human from the standpoint of the dialectical unity of its dual nature: as a social being, a subject of history, and a representative of a biological species, a living organism. $\mathrm{H}$. Root, a well-known German pedagogical antropologist, sees the goal of the human formation process in achieving "responsible behavior in which a human finds himself and achieves his highest purpose". Therefore, the task of pedagogical anthropology is to find and use the internal, spiritual prerequisites for the personality formation in the responsible, volitional action of the individual ${ }^{34}$. Root emphasizes that the most important thing in this way is the strengthening of a person's ability to act responsibly, which, in a complex of cross-effects of environment and heredity, contribute to the free moral choice of a human. He thinks that the internal spiritual structure created as a result of communication with others and own experience, learning and education is decisive for a self-determined and strong-willed human, rather than hereditary (physiological) features.

And here we return to the role of extremality in reforming the human life, which, in one way or another, has been forming for decades. O.F. Bolnov argues that a crisis opens a new beginning: "Every new life begins with a crisis". Crisis carries recovery, 'rejuvenation' of human life ${ }^{35}$. In the article "Perception of Information by the Subject as Threatening", we find evidence that the subject processes such information in a different way than the information, which does not contain any threatening content. This refers to the course of such cognitive processes as perception, imagination, memory, thinking, and so on. "Assessing the personal significance of threatening information activates the strategy of attention focusing on such information. It is accompanied with the emergence of appropriate cognitive, affective, behavioral and physiological patterns, evolutionarily aimed at survival and security" ${ }^{\prime 36}$.

Activation of a information processing method, in which the threat setting prevails, is characterized with: 1) autonomous excitation - preparation for

33 Цьось А.В. Система здорового способу життя в «Поученні» Володимира Мономаха. Історія педагогіки, психології, освіти. 1998. № 2. С. 208-216.

${ }^{34}$ Яркина Т.Ф. Педагогическая антропология за рубежом. О I томе монографии Генриха Роота. Советская педагогика. 1968. № 12. С. 143-146.

${ }^{35}$ Куликов В.Б. Педагогическая антропология: истоки, направления, проблемы. Свердловск : Изд-во Урал. ун-та, 1988. 192 с.

36 Носенко Є.Л. Сприйняття суб'єктом інформації як загрозливої. Педагогіка і психологія. 1998. № 3. С. 93. 
protective actions; 2) behavioral mobilization and blocking, i.e. preparing to get out of the situation or its prevention to reduce the risk and danger; 3 ) narrowing of the vectors of cognitive effort, their concentration on the threatening information; 4) a feeling of fear; 5) high attention to all signs of threat. The authors of the article note an interesting fact: "The above peculiarities of behavior were observed both in the case of clinical anxiety and in laboratory studies, which simulated normal anxiety"37.

Setting on the selective perception of threatening information, formed at the stage of activation, dominates and imposes anxious thoughts on the individual. There is also experimental evidence of better involuntary memorization of threatening information due to the anxiety experienced by the individual and the focus on threatening information.

Therefore, when training future teachers, it is absolutely necessary, first of all, to convince them of the need to self-determine in a position of active self-care, to encourage them to master the practice of building up their own health. Beside the fact that it is good for them, it is also important for the teacher to be an example to the students so that they could develop an active attitude to own health.

Secondly, future teachers need to master the necessary minimum of skills of psychological and pedagogical influence, which should be used in everyday activities. Obviously, in order to consolidate the achieved effect of physical education, it is necessary to orient more carefully than it usually happens, and to guide students to further active care of their own health, depending on the existing pathologies.

Thirdly, when a child understands that he/she is able to improve his or her own health through systematic and useful efforts, including those recommended by the teacher, he or she 'reduces' the level of threat and 'increases' awareness of his or her own ability to overcome the situation in which he or she finds himself/herself. This is how self-determination to building-up own health takes place.

\section{CONCLUSIONS}

1. Health build-up is a system of creative human activity to form and maintain own optimal health. It is based on the achievements of mankind: the ancient philosophical and educational concept (principle) of epimelia; theory of education and pedagogical anthropology; the concept of physical education by P.F. Lesgaft; methodology of mental activity; provisions of philosophy, pedagogy and psychology concerning education and upbringing, thinking and consciousness, human life, health and activity.

2. The principle of epimelia (self-care) as an important reference point for educational systems, can serve as a methodological basis for health

${ }^{37}$ Носенко Є.Л. Сприйняття суб'єктом інформації як загрозливої. Педагогіка і психологія. 1998. № 3. С. 94. 
protection activities of the students - future teachers according to the following algorithm: belief in the need for self-determination in the position of active self-care; encouraging them to master the practice of building up their own health; mastering the necessary minimum of skills of psychological and pedagogical influence; guiding the students in a methodically correct way to further active care for their own health, depending on the existing pathologies.

\section{SUMMARY}

The article substantiates the importance of encouraging future teachers to build up their own health. Beside the obvious benefits to the teacher, selfcare that requires adherence to the principle of epimelia helps the future teacher to set an important personal example for his students. Epimelia means an action by which a person not only takes care of himself, but also changes, purifies and transforms himself. Teachers convincing advice on how to follow the recommendations that should be followed in daily life will help to improve their health. When training future teachers, it is absolutely necessary, first of all, to convince them of the need to self-determine in a position of active self-care, to encourage them to master the practice of building up their own health. Therefore, the principle of epimelia as an important reference point for educational systems, can serve as a methodological basis for health protection activities of the students - future teachers. The algorithm of this process is following: belief in the need for self-determination in the position of active self-care; encouraging them to master the practice of building up their own health; mastering the necessary minimum of skills of psychological and pedagogical influence; guiding the students in a methodically correct way to further active care for their own health, depending on the existing pathologies.

\section{REFERENCES}

1. Буякас Т.М. Проблема и психотехника самоопределения личности. Вопросы психологии. 2002. С. 28-39.

2. Гадамер Х.-Г. Истина и метод: Основы филос. герменевтики / пер. с нем. ; общ. ред. и вступ. ст. Б.Н. Бессонова. Москва : Прогресс, $1988.704 \mathrm{c}$.

3. Загорский В.В. «Вальфдорское» преподавание химии. Химия в школе. 1995. № 3. С. 10-13.

4. Зинченко В.П. Совокупная деятельность как генетически исходная единица психического развития. Психологическая наука $u$ образование. 2000. № 2. С. 86-95.

5. Кареев Н. Идеалы общего образования. Alma mater. 1992. № 1. C. 81-86.

6. Концевич И.М. Стяжание духа святаго. Киев : Изд. Экзарха всей Украины Митрополита Киевского и Галицкого, 1990. 52 с. 
7. Кузьмик В. Принципи християнської моралі - основа здорового способу життя сучасної людини. Острозька Академія. Наукові записки. Т. 3. Виховання молодого покоління на принципах християнської моралі в проиесі духовного відродження Украӥни. Острог, 2000. С. 347-373.

8. Куликов В.Б. Педагогическая антропология: истоки, направления, проблемы. Свердловск : Изд-во Урал. ун-та, 1988. 192 с.

9. Мясоед П.А. Антропологический принцип и проблемы психологии развития. Вопросы психологии. 2000. № 5. С. 122-126.

10. Никитин В.А. К представлению об исторических циклах университетского образования. Вопросы методологии. 1991. № 2. C. $67-68$.

11. Носенко Є.Л. Сприйняття суб'єктом інформації як загрозливої. Педагогіка і психологія. 1998. № 3. С. 90-99.

12. Приходько В.В. Стратегія реформи національної вищої школи : монографія. Дніпропетровськ : Журфонд, 2014. 460 с.

13. Репецкий Ю.А. Концепция личностного самоопределения: исходные положения и попытка их верификации. Нова парадигма. Вип. 2. 1997. С. 8-13.

14. Розанов В.В. Сумерки просвещения. Москва : Педагогика, 1990. $624 \mathrm{c}$.

15. Скрипкина Т.П. Доверие к себе как условие развития личности. Вопросы психологии. 2002. № 1. С. 95-103.

16. Слободчиков В.И. Антропологический принцип в психологии развития. Вопросы психологии. 1998. № 6. С. 3-17.

17. Сущенко Л.П. Історико-філософський аспект становлення поняття «здоровий спосіб життя» людини у давньому світі та середніх віках. Нова парадигма. Вип. 2. 1997. С. 42-47.

18. Томенко О.А. Особливості теоретичних уявлень майбутніх вчителів фізичної культури стосовно питань аксіологічного та здоров'язбережного спрямування. Спортивна наука України. 2013. № 1. C. 44-47. URL: http://www.sportscience.org.ua/index.php/Arhiv.html.

19. Томенко О., Матросов С. Відмінності у показниках соматичного здоров'я, рухової активності, теоретичної підготовленості й мотиваційної сфери старшокласників та студентів залежно від статі. Педагогічні науки: теорія, історія, інноваційні технології. 2018. № 9 (83). С. 113-123.

20. Фуко М. Герменевтика субъекта. Социо-Логос / пер. с англ., нем., франц. Москва : Прогресс, 1991. С. 284-311.

21. Чернігівська С.А. Інноваційна технологія непрофесійної фізкультурної освіти студентів, звільнених від практичних занять 3 «Фізичного виховання»: дис. канд. наук з фіз. вих. і спорту : 24.00.02. Дніпропетровськ, 2012. 290 с.

22. Чернігівська С.А. Модель будівничого власного здоров'я для інноваційної педагогічної технології непрофесійної фізкультурної 
освіти студентів, звільнених від «Фізичного виховання». Спортивний вісник Придніпров'я. 2011. № 2. С. 38-40.

23. Чернігівська С.А., Шевяков О.В. Особливості психічних станів студентів, звільнених від практичних занять 3 «Фізичного виховання». Вісник Чернігівського державного педагогічного університету. Вип. 91. 2011. С. 491-495.

24. Чернышевский Н.Г. Антропотехнический принцип в философии. Избр. филос. соч. : в 3 т. Москва : Госуд. изд-во политич. литер., 1951. T. 3. C. $162-254$.

25. Цьось А.В. Система здорового способу життя в «Поученні» Володимира Мономаха. Історія педагогіки, психології, освіти. 1998. № 2. C. 208-216.

26. Яркина Т.Ф. Педагогическая антропология за рубежом. O I томе монографии Генриха Роота. Советская педагогика. 1968. № 12. C. $143-146$.

\section{Information about the authors: \\ Chernihivska S. A.,}

$\mathrm{Ph}$. D. in Physical Education and Sports Sciences, Associate Professor at the Physical Education and Sports Department

National Technical University Dnipro Polytechnic 19, Dmytra Yavornytskoho avenue, Dnipro, 49005, Ukraine

Matrosov S. O., Ph. D. Student Sumy State Pedagogical University named after A. S. Makarenko 87, Romenska str., Sumy, 40002, Ukraine 